Southern Illinois University Carbondale

OpenSIUC

Publications

Department of Zoology

$12-1-2010$

\title{
A New Species of Cyclobulura (Nematoda: Subuluridae) from Zaedyus pichiy and Chaetophractus vellerosus (Xenarthra: Dasypodidae) in Argentina
}

Graciela T Navone

María C Ezquiaga

Juliana Notarnicola

F Agustín Jiménez-Ruiz

Southern Illinois University Carbondale, agustinjz@siu.edu

Follow this and additional works at: http://opensiuc.lib.siu.edu/zool_pubs

Published in the Journal of Parasitology, Vol. 96, No. 6 (2010): 1191-1196.

Copyright 2006, American Society of Parasitologists.

Used by permission.

\section{Recommended Citation}

Navone, Graciela T, Ezquiaga, María C, Notarnicola, Juliana and Jiménez-Ruiz, F Agustín. "A New Species of Cyclobulura (Nematoda: Subuluridae) from Zaedyus pichiy and Chaetophractus vellerosus (Xenarthra: Dasypodidae) in Argentina." 96, No. 6 (Dec 2010).

This Article is brought to you for free and open access by the Department of Zoology at OpenSIUC. It has been accepted for inclusion in Publications by an authorized administrator of OpenSIUC. For more information, please contact opensiuc@lib.siu.edu. 


\title{
A NEW SPECIES OF CYCLOBULURA (NEMATODA: SUBULURIDAE) FROM ZAEDYUS PICHIY AND CHAETOPHRACTUS VELLEROSUS (XENARTHRA: DASYPODIDAE) IN ARGENTINA
}

\author{
Graciela T. Navone, María C. Ezquiaga, Juliana Notarnicola, and F. Agustín Jiménez \\ Centro de Estudios Parasitológicos y de Vectores-CEPAVE, CONICET-UNLP, Calle 2, no. 584, (1900) La Plata, Argentina. e-mail: gnavone@ \\ cepave.edu.ar
}

\begin{abstract}
Cyclobulura superinae n. sp. collected from Zaedyus pichiy and Chaetophractus vellerosus is herein described as the second species in Cyclobulura Quentin, 1977, and the first subulurid in armadillos. The species is unique in the spur-like structures present at the tip of both spicules, yet they conform to the description of Cyclobulura in the structure of the buccal parts. Specimens of the new species show longer chordal lobes and more conspicuous radial lobes and are smaller than specimens of $C$. lainsoni. In addition, males of $C$. superinae exhibit a spur-like process in the distal end of the spicules and a shorter tail ( $170 \mathrm{vs} .300 \mu \mathrm{m})$ with no spine. Finally, the eggs of $C$. superinae are smaller $(60-89 \times 45-71$ vs. $95-100 \times 80-85)$. To our knowledge, the new species is the first subulurid nematode found in an armadillo.
\end{abstract}

Armadillos (Cingulata), anteaters, and sloths (Pilosa) constitute the Xenarthra, the basal group of the 4 major clades of placental mammals (Delsuc et al., 2002) and 1 of the most ancient groups represented in the Neotropical Region (Redford and Eisenberg, 1992). More than 21 species of armadillos are present in Argentina alone, occupying different habitats such as the Neotropical forest and the puna, chaco, and semiarid areas in Patagonia (Wetzel, 1985). Several species of parasites, mainly nematodes, have been described from armadillos collected in Argentina (Navone and Lombardero, 1980; Chabaud et al., 1983; Navone, 1983, 1986, 1987a, 1987b; Notarnicola and Navone, 2003). The correlation among helminth communities and food habits of armadillos from Argentina has been studied in detail (Navone, 1990).

The pichi, Zaedyus pichiy (Desmarest, 1804) (Dasypodidae), is a small armadillo that inhabits arid and semiarid areas of Argentina and Chile (Wetzel, 1985). This species is omnivorous and opportunistic in its feeding habits (Superina and Boily, 2007). The screaming hairy armadillo Chaetophractus vellerosus (Gray, 1865) (Dasypodidae) is a medium-sized species occurring in xeric regions of Argentina, Bolivia, and Paraguay; it is a systematic forager (Cassini, 1993), with habits and diet switching seasonally from insectivorous in the summer to herbivorous in the winter (Greegor, 1985).

Wild populations of $Z$. pichiy in Mendoza province, Argentina, have been monitored to understand their ecology (Superina, 2008). As a result of that research program, Ezquiaga et al. (2009) observed the presence of eggs from nematodes belonging to 3 known species and 1 unidentified Cyclobulura sp. Quentin 1977 (Ascaridida: Subuluridae). Subsequently, 4 dead pichis were confiscated from poachers and became available for parasitological examination. Additional species of armadillos from La Rioja province, including C. vellerosus Gray, 1865, were examined for parasites.

The aim of the present study is to describe a new species of Cyclobulura parasitizing the pichi from Mendoza and $C$. vellerosus from La Rioja, which constitutes the first subulurid nematode found in armadillos and the second known species of the genus.

Received 24 May 2010; revised 3 August 2010; accepted 9 August 2010. * Department of Zoology, Southern Illinois University, Carbondale, Illinois 62901-6501.

DOI: 10.1645/GE-2549.1

\section{MATERIALS AND METHODS}

Four individuals of $Z$. pichiy were confiscated from poachers in the following localities from Mendoza province, Argentina: Lavalle $32^{\circ} 50^{\prime} \mathrm{S}$, $67^{\circ} 53^{\prime} \mathrm{W}(\mathrm{n}=1)$; San Rafael $34^{\circ} 21^{\prime} \mathrm{S}, 68^{\circ} 32^{\prime} \mathrm{W}(\mathrm{n}=1)$; Malargüe $35^{\circ} 38^{\prime} \mathrm{S}$, $68^{\circ} 34^{\prime} \mathrm{W}(\mathrm{n}=1)$; and San Carlos $34^{\circ} 16^{\prime} \mathrm{S}, 69^{\circ} 8^{\prime} \mathrm{W}(\mathrm{n}=1)$, during $2002-$ 2003. Eight individuals of C. vellerosus were collected by M.C.E. from Salina La Antigua $30^{\circ} 02^{\prime} 54^{\prime \prime} \mathrm{S}, 66^{\circ} 03^{\prime} 51^{\prime \prime} \mathrm{W}(\mathrm{n}=6)$, Departamento Chamical, and Paraje Punta de los Llanos $30^{\circ} 08^{\prime} \mathrm{S}, 66^{\circ} 32^{\prime} \mathrm{W}(\mathrm{n}=2)$, Departamento Capital, La Rioja, in July 2009.

The digestive tract of specimens was fixed in a $10 \%$ formaldehyde solution and dissected in the laboratory. The nematodes found were preserved in $70 \%$ ethanol. Specimens were cleared in lactophenol, mounted on a slide under a cover slip, and studied using a compound microscope. A cross section of the anterior end of both male and female was made to obtain an en face view. Drawings were made using an Olympus BX 51 microscope equipped with a drawing tube. Some specimens were dehydrated in a series of $70 \%, 80 \%, 90 \%, 95 \%$, and $100 \%$ ethanol, dried with the critical point method, and photographed using a Jeol/SET $100^{\circledR}$ scanning electron microscope (SEM).

Measurements are given in micrometers, unless otherwise stated; those of paratypes are expressed as the mean \pm the standard deviation followed by range values in parentheses (Sokal and Rohlf, 1995). Nematodes were deposited in the Colección de Helmintos Museo de La Plata (CHMLP), La Plata, Buenos Aires, Argentina, the Parasite Collection of the Harold W. Manter Laboratory of Parasitology (HWML) of the University of Nebraska, Lincoln, Nebraska, and the National Parasite Collection (USNPC) Bethesda, Maryland, and hosts in the Colección de Mastozoología Museo de La Plata (MLP).

We also studied paratype specimens of Cyclobulura lainsoni Quentin, 1977, MNHN 156RL, deposited in the Museum National de Histoire Naturelle, Paris, France.

\section{DESCRIPTION \\ Cyclobulura superinae $\mathbf{n}$. sp. \\ (Figs. 1-19; Table I)}

General diagnosis: Whitish nematodes with both ends gradually tapering. Males and females with identical buccal and pharyngeal structures (Fig. 1). Six inner labial papillae; 4 conspicuous cephalic papillae and lateral amphids (Fig. 14). Circular stoma (Figs. 2, 14). Buccal capsule divided in 2 parts; anterior buccal part with thick cuticularized walls (cheilostome sensu Inglis, 1966), and posterior pharyngeal part (esophagostome sensu Inglis, 1966) with cuticularized walls connected with both pharyngeal lobes and with twisted chordal and radial lobes; chordal lobes rounded and poorly developed, fused on basis with radial lobes (Fig. 1). Buccal cavity with tripartite arrangement in a transverse section (Figs. 3-5)

Males: Tail tapering to a rounded point, without spine (Fig. 10). Spicules subequal, with a dorsal spur-like structure at distal end, structure arises in $90^{\circ}$ angle from main axis of spicule, and backwards (Fig. 12). Gubernaculum present (Fig. 13). Ventral precloacal sucker, elongate, with 


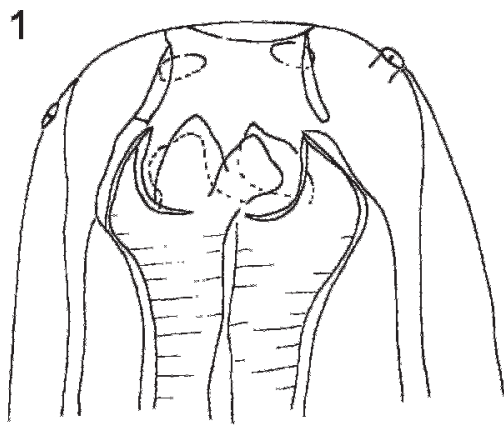

2

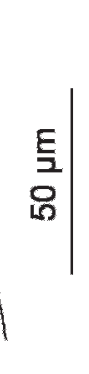

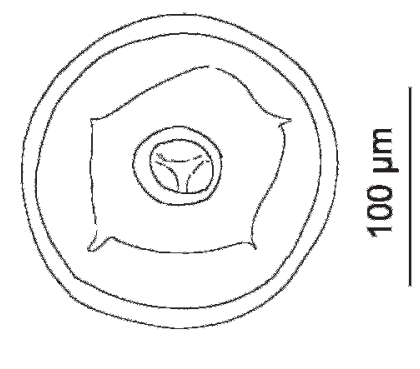

3

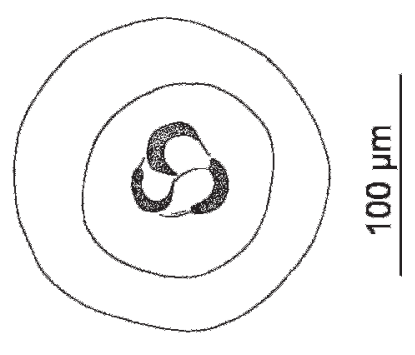

6

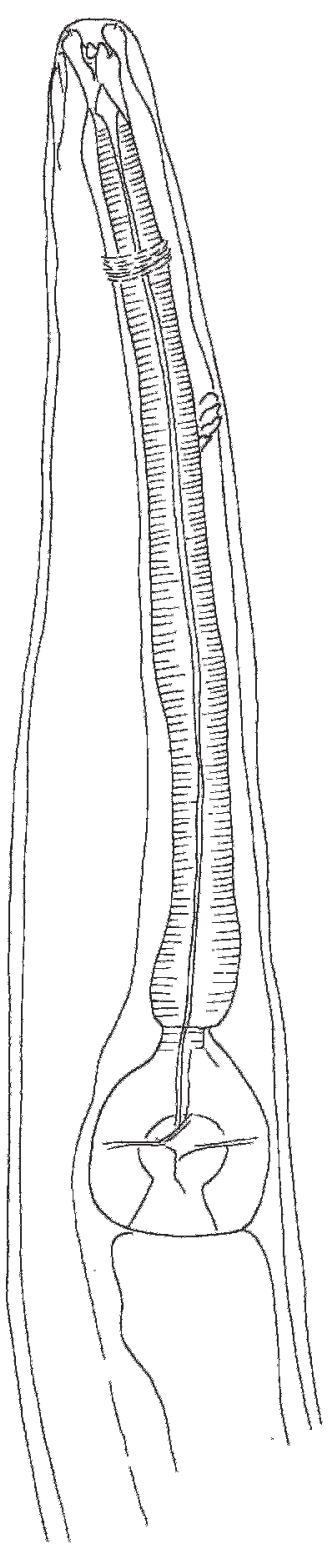

4

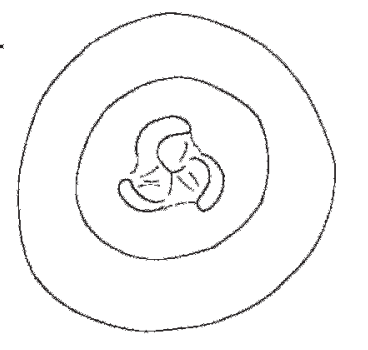

특

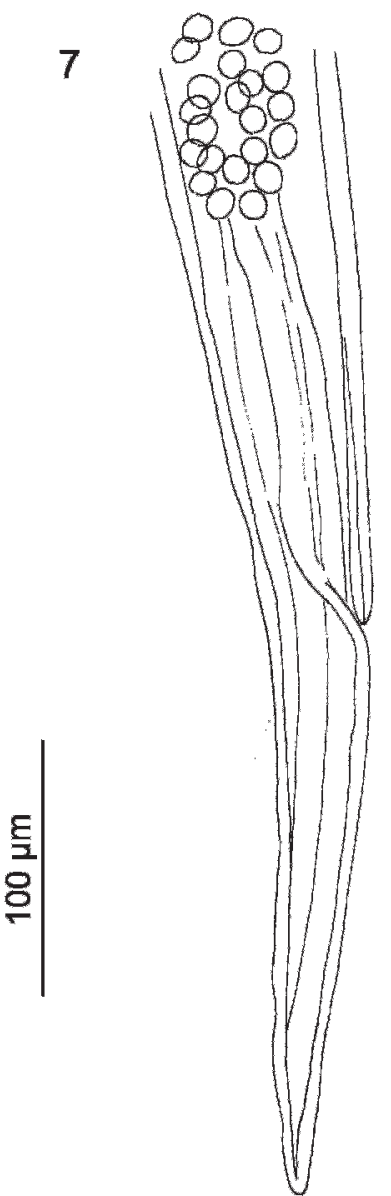

5

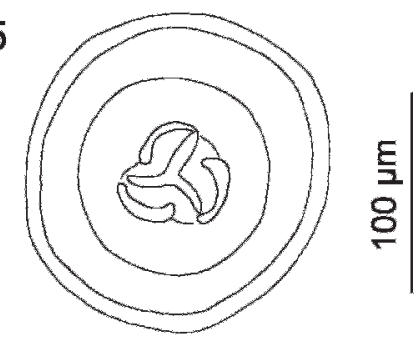

8
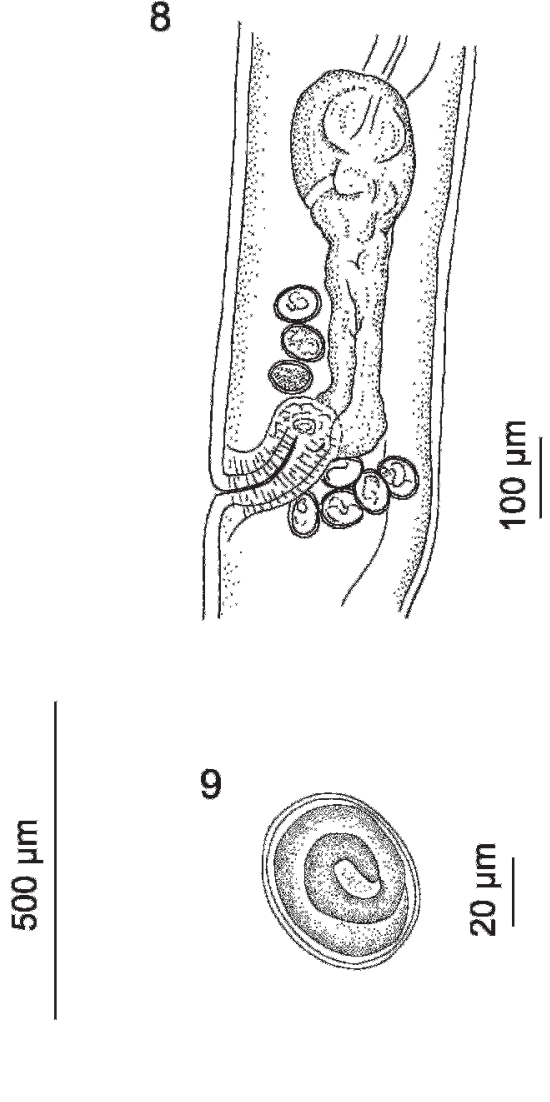

틈

\section{9}

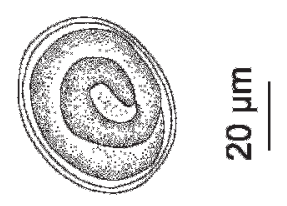

FIgUREs 1-9. Cyclobulura superinae. Female: (1) Anterior extremity showing chordal, pharyngeal, and radial lobes. (2-5) Apical view: (2) at level of stoma, (3-5) at level of lobes. (6) Anterior region, lateral view. (7) Posterior extremity, lateral view. (8) Detail of vulva. (9) Embryonated egg. 
11

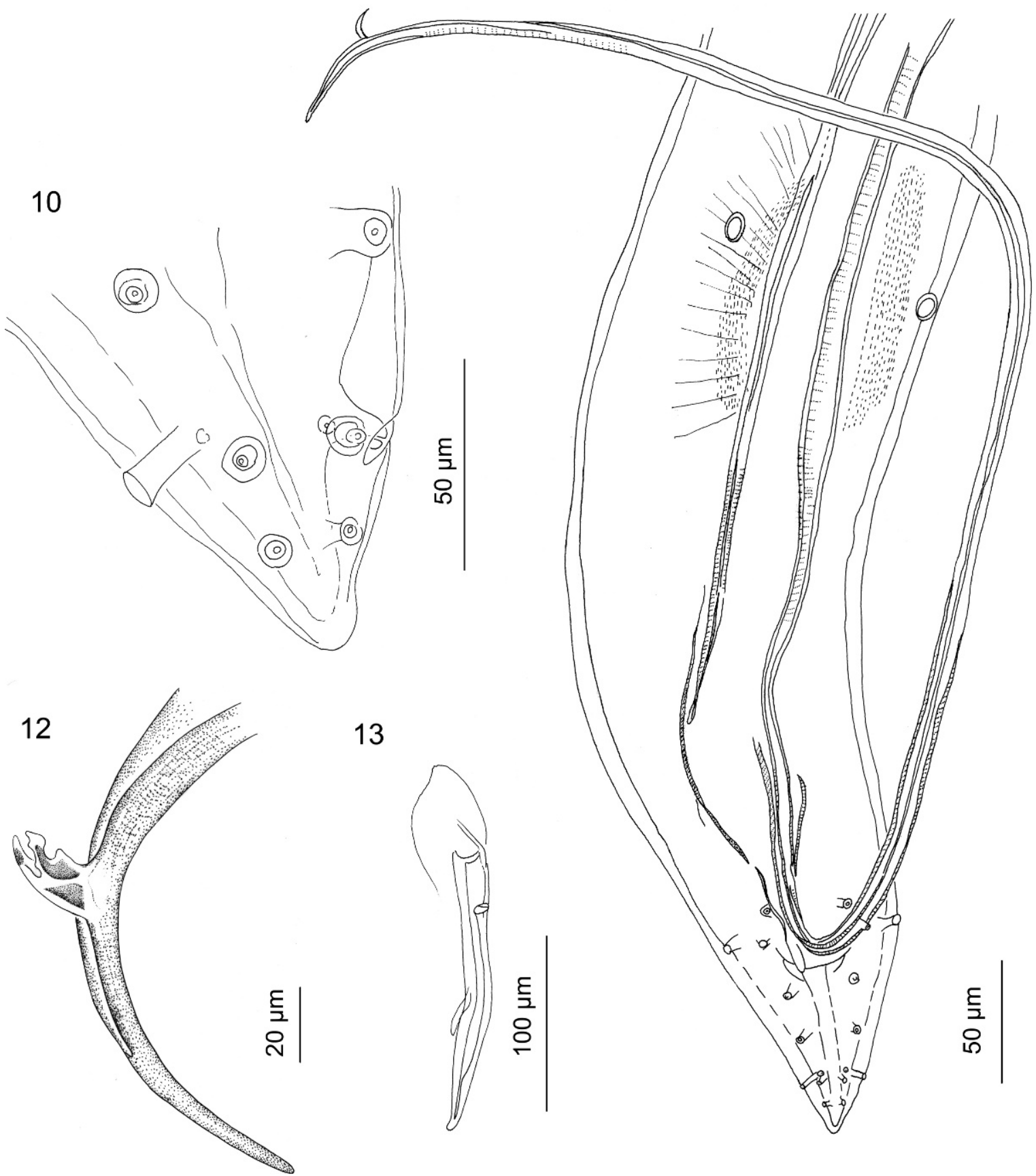

Figures 10-13. Cyclobulura superinae. Male: (10) Caudal extremity showing postcloacal papillae. (11) Posterior extremity showing sucker, spicules, and papillae. (12) Extremity of the spicule with dorsal spur-like structure. (13) Gubernaculum.

transversal cuticular striations (Fig. 15). Nine pairs of caudal papillae arranged as follows: 1 pair at level of sucker; 3 subventral lateral pairs; single precloacal median; 4 subventral and 1 postcloacal lateral pair (Fig. 11); phasmids present between 7th and 8th pair of subventral papillae (Figs. 16, 17).

Holotype: Body length $9 \mathrm{~mm}$, width at mid-body 368. Nerve ring and excretory pore located 286 and 503, respectively, from anterior end. Buccal cavity 75 long. Total length of esophagus 1,535. Corpus 1,426 long; esophageal bulb 223 long by 238 at maximum width. Spicules 2,641 and 2,593 long. Gubernaculum 205 long by 16 wide. Sucker located 640 from posterior end and 190 in diameter. Tail length 170; phasmids 54 from tip tail.
Paratypes ( $n=18$ unless otherwise indicated): Body length $9.4 \mathrm{~mm} \pm 1$ $(8-12)$, width at mid-body $381.7 \pm 65.4(277-495)(\mathrm{n}=16)$. Nerve ring and excretory pore located $328.6 \pm 73.8(180-467)(\mathrm{n}=14)$ and $591.9 \pm$ $76.6(498-783)(\mathrm{n}=17)$ from anterior end, respectively. Buccal cavity 54.3 $\pm 9.2(42-68)(\mathrm{n}=10)$ long. Total length of esophagus $1,727 \pm 153.3$ $(1,303-1,944)(\mathrm{n}=17)$; corpus $1,438.7 \pm 64.3(1,346-1,570)(\mathrm{n}=11)$ long; width at level of nerve ring $109.2 \pm 35.5(45-165)(\mathrm{n}=10)$. Bulb of esophagus $255.4 \pm 34.7(185-332)(\mathrm{n}=16)$ long by $258.4 \pm 36(190-332)$ $(\mathrm{n}=15)$ at maximum width. Left spicule $2,452.2 \pm 285.6(1,746-2,822)(\mathrm{n}$ $=16)$ long, right spicule $1,893 \pm 664.5(1,103.7-2,823)(\mathrm{n}=7)$ long. Gubernaculum $206.9 \pm 23(150-244)(\mathrm{n}=18)$ long by $23.4 \pm 3.1(17-27)$ $(\mathrm{n}=9)$ wide. Sucker $625.2 \pm 105(450-805)(\mathrm{n}=12)$ from posterior end 

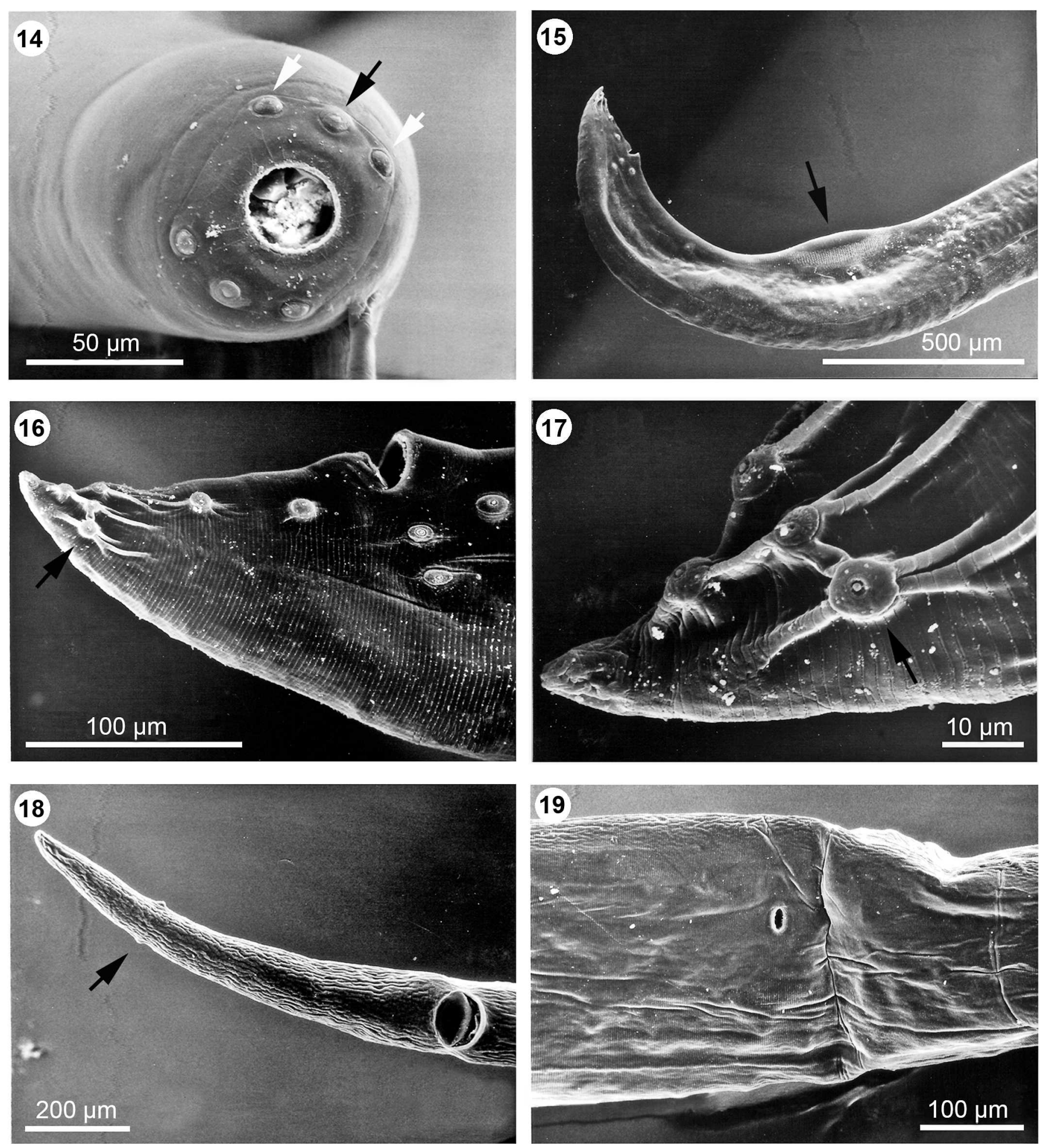

FIGUREs 14-19. SEM micrographs of Cyclobulura superinae. (14) Apical view. Black arrow shows amphids, white arrows show cephalic papillae. (15) Male tail showing the ventral sucker. (16) Detail of caudal papillae. The arrow shows the left phasmid. (17) Detail of phasmids. (18) Female, posterior extremity. The arrow shows the phasmids. (19) Detail of vulva.

and $198.5 \pm 43.4(150-286)(\mathrm{n}=11)$ in diameter. Tail length $167 \pm 19.9$ (133-197) with phasmids at $42 \pm 5(36-45)(\mathrm{n}=3)$ from end of tail.

Females: Vulva at mid-body. Ovijector simple (Figs. 8, 19). Oval eggs with thin shell, embryonated in the uterus (Fig. 9). Tail elongated, tapering to conical tip (Fig. 7). Phasmids conspicuous (Fig. 18).
Allotype: Body length $13 \mathrm{~mm}$, width at level of vulva 304. Excretory pore located 488 from anterior end. Buccal cavity 74 long. Total length of esophagus including bulb 1,313. Corpus length 1,080 by 117 wide. Bulb of esophagus 264 long by 239 wide. Vulva located $6 \mathrm{~mm}$ from anterior end. Tail 948 long. Eggs $73 \pm 7.3(60-89)$ by $61 \pm 5.5(45-71)(\mathrm{n}=27)$. 
TABLE I. Measurements of males and females of Cyclobulura superinae n. sp. from Chaetophractus vellerosus collected in La Rioja province, Argentina.

\begin{tabular}{lcc}
\hline & Males $(\mathrm{n}=5)$ & Females $(\mathrm{n}=5)$ \\
\hline Body length (mm) & $9.2(8.3-10.6)$ & $13.7(13-14.1)$ \\
Maximum width & $457.5(400-500)$ & $594(530-650)$ \\
Buccal cavity & $52.5(50-60)$ & $69(60-75)$ \\
Excretory pore* & $650(540-720)$ & $756(520-1,100)$ \\
Nerve ring* & $490(350-420)$ & $476(410-670)$ \\
Esophagus length & $1,985(1,870-2,060)$ & $2,298(2,250-2,400)$ \\
Corpus length $\times$ width & $1,717.5(1,600-1,800) \times 87.5(70-110)$ & $2,024(1,970-2,150) \times 106(80-170)$ \\
Bulb length $\times$ width & $267.5(260-270) \times 295(280-300)$ & $274(250-330) \times 316(290-350)$ \\
Tail & $178(160-200)$ & $1,022(890-1,170)$ \\
Sucker to cloaca & $398(310-450)$ & - \\
Sucker length & $192(150-240)$ & - \\
Spicule length & $3,074(2,500-3,520)$ & - \\
Gubernaculum & $208(180-240)$ & - \\
Sucker from post end & $576(480-650)$ & $6.7(5.3-7.7)$ \\
Vulva* $(\mathrm{mm})$ & - & $68.4(60-79) \times 54.9(48-65)$ \\
Eggs long $\times$ wide $(\mathrm{n}=11)$ & - & -
\end{tabular}

* Measures to the anterior end.

Paratypes ( $n=15$ unless otherwise indicated): Body length $12.8 \mathrm{~mm} \pm$ $1.4(11-15 \mathrm{~mm})(\mathrm{n}=13)$, width at level of vulva $455.7 \pm 80(347-557)(\mathrm{n}=$ 9). Nerve ring and excretory pore located $369.7 \pm 41.7(300-405)(n=8)$ and $617.2 \pm 78.6(515-717)(\mathrm{n}=11)$ from anterior end, respectively. Buccal cavity $68.1 \pm 15.5(43-84)(n=7)$ long. Total length of esophagus including bulb $1,899.9 \pm 321.5(1,265-2,275)(\mathrm{n}=12)$; corpus 1,526 \pm $337.5(1,034-1,885)$ long, by $130 \pm 45.2(75-183)(n=7)$ wide; esophageal bulb $321 \pm 56.2(224-428)$ long by $283.4 \pm 59.3(191-390)(n=14)$ wide. Vulva located $6.3 \mathrm{~mm} \pm 0.7(5-8 \mathrm{~mm})(\mathrm{n}=9)$ from anterior end. Tail $825.7 \pm 149.9(637-1,118)(n=13)$ long. Eggs $67 \pm 10.7(52-80)(n=12)$ by $55 \pm 9.5(39-78)(\mathrm{n}=12)$. Measurements of specimens collected from C. vellerosus are given in Table I.

\section{Taxonomic summary}

Type host: Zaedyus pichiy (Desmarest, 1804) deposited at Colección de Mastozoología Museo de la Plata, La Plata, Argentina, MLP 7.V.10.2 (ZP50).

Other hosts: Chaetophractus vellerosus Gray, 1865, MLP 7.V.10.3 (CO36).

Type locality: San Carlos $\left(34^{\circ} 16^{\prime} \mathrm{S}, 69^{\circ} 8^{\prime} \mathrm{W}\right)$, Mendoza, Argentina.

Other localities: Salina La Antigua $\left(30^{\circ} 02^{\prime} 54^{\prime \prime} \mathrm{S}, 66^{\circ} 03^{\prime} 51^{\prime \prime} \mathrm{W}\right)$, Departamento Chamical, La Rioja, Argentina.

Site of infection: Small intestine and caecum.

Specimens deposited: Holotype CHMLP 6135; allotype CHMLP 6136; paratypes CHMLP 6137 and voucher 6138. Additional specimens: HWML 64573 and USNPC 103073.

Prevalence and mean intensity: In Z. pichiy: 75\% (3 of 4 prospected specimens); 126 (12-337) parasites per hosts. In C. vellerosus: $33 \%$ (2 of 6 prospected); 10 worms per host.

Etymology: The species is named after Dr. Mariella Superina, earnest researcher of the biology and conservation of the pichi Z. pichiy and other armadillos occurring in Mendoza, Argentina.

\section{Remarks}

The general morphology of the specimens herein described conforms to the description of the monotypic Cyclobulura, and it resembles $C$. lainsoni in the structures present in the anterior end, including circular stoma, pharyngeal cavity with cuticularized walls, and twisted chordal and radial lobes fused at the base. In addition, they share a similar disposition of ventral sucker, caudal papillae, and length of the spicules (Quentin, 1977). However, specimens of $C$. lainsoni are larger than those of $C$. superinae, and the spicule-body length ratio is greater in the latter than in the former $(0.28$ vs. 0.08$)$. Males of $C$. superinae possess a proportionally shorter tail, with no caudal spine, and the spicules possess a distinctive spur-like process in the distal end. Moreover, the vulva in specimens of $C$. superinae opens at the mid-body region, while in $C$. lainsoni it opens in the anterior third; the chordal lobes in $C$. superinae are longer, and the radial lobes are conspicuous, as opposed to the atrophied lobes present in $C$. lainsoni.

Cyclobulura is a genus of the Labiobulurinae Quentin, 1969, which is characterized by the cuticularized pharyngeal lobes. The subfamily includes Labiobulura Skrjabin and Schikhobalova, 1948, parasites of Australian marsupials, and Tarsubulura Inglis, 1958, parasites of tupaids, lorisids, and tarsioids in Asia (Quentin, 1969, 1977; Smales, 2009). The new species also differs from these 2 genera in having a circular stoma, instead of a hexagonal one, or with 6 labial lobes. Other genera in Subuluroidea possess muscular pharyngeal lobes, while they seem to be cuticularized in Cyclobulura (Quentin, 1969; Chabaud, 1978; Smales, 2009).

\section{DISCUSSION}

Previous to this description, Cyclobulura included C. lainsoni collected from the silky anteater Cyclopes didactylus (Linnaeus, 1758) (Pilosa: Cyclopedidae) from Belem, Brazil (Quentin, 1977). This species is distributed from southern Mexico to southern Brazil, inhabiting the canopy of the rainforest (Best and Harada, 1985). In contrast, the pichi $Z$. pichiy is restricted to central and southern Argentina, living in arid habitats with firm sandy soils, such as the steppe in southern Mendoza; C. vellerosus is found inxeric areas of the Gran Chaco of Bolivia, western Paraguay, and Argentina (Redford and Eisenberg, 1992). These species of armadillos do not overlap in their distribution, do not occur in similar habitats, and are somewhat distantly related to the silky anteater. Nonetheless, these mammals are insectivorous, with the armadillos having a wide spectrum diet and the silky anteater being myrmecophagous (Navone, 1990; Redford and Eisenberg, 1992). Subuluroids use arthropods as intermediate hosts, such as larvae of coleopterans, cockroaches, and crickets (Quentin et al., 1977; Anderson, 2000). It is expected that similar invertebrates would serve as intermediate hosts in the life cycle of species of Cyclobulura.

Long-term studies on parasites of Dasypodidae from Argentina have been in progress since 1980 (Navone and Lombardero, 1980; Navone, 1986, 1987a, 1987b, 1990; Notarnicola and Navone, 2003; Ezquiaga et al., 2009). The discovery of additional species occurring in armadillos elsewhere (Jiménez-Ruiz and Gardner, 2003; Jiménez-Ruiz et al., 2006) and the parasite herein described 
suggests that the diversity of parasites of Xenarthrans may be greater than previously thought, and that the discovery of species would necessitate the survey of the diverse biomes across the Americas.

\section{ACKNOWLEDGMENTS}

We thank Mariella Superina for collecting armadillos, Cecilia Carballo for laboratory assistance, and Patricia Sarmiento for assistance with the SEM micrographs. María Cristina Estivariz assisted with the drawings. This study was funded by Consejo Nacional de Investigaciones Científicas y Técnicas (CONICET)

\section{LITERATURE CITED}

Anderson, R. C. 2000. Nematode parasites of vertebrates: Their development and transmission, 2nd ed. CABI Publishing, Farnham Royal, U.K., 650 p.

Best, R. C., AND A. Y. Harada. 1985. Food habits of the silky anteater (Cyclopes didactylus) in the central Amazon. Journal of Mammalogy 66: $780-781$.

CAssini, M. H. 1993. Searching strategies within food patches in the armadillo Chaetophractus vellerosus. Animal Behaviour 46: 400-402.

Chabaud, A. G. 1978. CIH Keys to the nematode parasites of vertebrates. No. 6. Keys to genera of the superfamilies Cosmocercoidea, Seuratoidea, Heterakoidea and Subuluroidea. Commonwealth Agricultural Bureaux International, Farnham Royal, U.K., 71 p.

, G. T. Navone, And O. Bain. 1983. Description de Mazzia bialata n. sp., parasite de Dasypodidés: Attribution du genre aux nématodes Spirocercidae. Bulletin du Museum National d'Histoire Naturelle, Paris, 4e série, 5. section A: 175-179.

Delsuc, F., M. Scally, O. Madsen, M. J. Stanhope, W. W. de Jong, F. M. Catzeflis, M. S. Springer, and E. J. P. Douzery. 2002. Molecular phylogeny of living Xenarthrans and the impact of character and taxon sampling on the placental tree rooting. Molecular Biology and Evolution 19: 1656-1671.

Ezquiaga, M. C., M. Superina, and G. T. Navone. 2009. Parásitos intestinales de Zaedyus pichiy (Xenarthra: Dasypodidae) de Mendoza, Argentina. Mastozoología Neotropical 16: 309-319.

GREEGOR, D. H., JR. 1985. Ecology of the little hairy armadillo Chaetophractus vellerosus. In The evolution and ecology of armadillos, sloths and vermilinguas, G. Montgomery (ed.). Smithsonian Institution Press, Washington, D.C., p. 397-406.

INGLIS, W. G. 1966. The origin and function of the cheilostomal complex in the nematode Falcaustra stewarti. Proceedings of the Linnean Society of London 177: 55-62.

JimÉnEZ-Ruiz, F. A., AND S. L. GARDNER. 2003. Aspidoderid nematodes from Bolivian armadillos, with the description of a new species of Lauroia (Heterakoidea: Aspidoderidae). Journal of Parasitology 89: 978-983.

-, and A. Varela-Stokes. 2006. Aspidoderidae from North America with the description of a new species of Aspidodera (Nematoda: Heterakoidea). Journal of Parasitology 92: 847-854.

Navone, G. T. 1983. Estudios parasitológicos en edentados argentinos. Ph.D. Thesis. Facultad de Ciencias Naturales y Museo, Universidad Nacional de La Plata, La Plata, Argentina, 106 p.
1986. Estudios parasitológicos en edentados argentinos. II. Nematodes parásitos de armadillos: Aspidodera fasciata (Schneider, 1866); Aspidodera scoleciformis (Diesing, 1851) y Aspidodera vazi Proença, 1937. (Nematoda-Heterakoidea). Neotropica 32: 71-79.

—. 1987a. Descripción del macho de Pterygodermatites (Paucipectines) chaetophracti (Navone y Lombardero, 1980) Sutton, 1984 (Nematoda-Rictulariidae). Neotropica (La Plata) 33: 45-49.

1987b. Estudios parasitológicos en edentados argentinos. III. Trichostrongylidos, Macielia elongata sp. nov; Moennigia virilis sp. nov. y Trichohelix tuberculata (Parona y Stossich, 1901) Ortlepp, 1922 (Molineidae-Anoplostrongylinae) parásitos de Chaetophractus villosus Desmarest y Tolypeutes matacus (Desmarest) (Xenarthra-Dasypodidae). Neotropica (La Plata) 33: 105-117.

-1990. Estudio de la distribución, porcentaje y microecología de los parásitos de algunas especies de edentados argentinos. Studies on Neotropical Fauna and Environment 25: 199-210.

-, AND O. LOMBARDERO. 1980. Estudios parasitológicos en edentados argentinos. I. Pterygodermatites (Pterygodermatites) chaetophracti en Chaetophractus villosus y Dasypus hybridus (Nematoda Spirurida). Neotropica (La Plata) 26: 65-70.

Notarnicola, J., and G. T. Navone. 2003. Systematics and distribution of Orihelia anticlava (Molin, 1858) (Nematoda, Onchocercidae) from dasypodids of South America. Acta Parasitologica 48: 103-110.

Quentin, J. C. 1969. Cycle biologique de Subulura williaminglisi Quentin, 1965. Ontogénèse des structures céphaliques. Valeur phylogénetique de ce caractère dans la classification des nématodes Subuluridae. Annales de Parasitologie humaine et comparée 44: 451-484.

- 1977. Cyclobulura lainsoni n. gen. n. sp., nématode Subulure parasite d'un Xenarthre d' Amerique du Sud. Bulletin du Museum National d'Histoire Naturelle, Paris 3 série Zoologie 326: 771-776.

, M. Krishnasamy, and R. Tcheprakoff. 1977. Cycle biologique de Tarsubulura perarmata (Ratzel, 1868). Annales de Parasitologie Humaine et Comparée 52: 159-170.

RedFord, K. H., And J. F. Eisenberg. 1992. Mammals of the Neotropics: The Southern Cone. Chile, Argentina, Uruguay, Paraguay. Vol. 2. University of Chicago Press, Chicago, Illinois, $430 \mathrm{p}$.

Smales, L. R. 2009. A review of the nematode genus Labiobulura (Ascaridida: Subuluridae) parasitic in bandicoots (Peramelidae) and bilbies (Thylocomyidae) from Australia and rodents (Murinae: Hydromyini) from Papua New Guinea with the description of two new species. Zootaxa 2209: 1-27.

SoKal, R. R., AND F. J. Rohlf. 1995. Biometry: The principles and practice of statistics in biological research, 3rd ed. W. H. Freeman, New York, New York, $887 \mathrm{p}$

SuperinA, M. 2008. The ecology of the pichi Zaedyus pichiy in western Argentina. In The biology of the Xenarthra, S. F. Vizcaino and W. J. Loughry (eds.). University Press of Florida, Gainesville, Florida, p. 313-318

, AND P. BoILy. 2007. Hibernation and daily torpor in an armadillo, the pichi (Zaedyus pichiy). Comparative Biochemistry and Physiology, Part A 148: 893-898.

Wetzel, R. M. 1985. Taxonomy and distribution of armadillos, Dasypodidae. In The evolution and ecology of armadillos, sloths, and vermilinguas, G. Montgomery (ed.). Smithsonian Institution Press, Washington, D.C., p. 23-46. 